\title{
Does Trade with Low-wage Countries Cause Wage Inequality?
}

\author{
JALEFI. AHMAD*
}

This paper investigates the question as to whxther trade with low-wage countries has contributed to wage inequality in high-income countries, as predicted by the Stolper-Sarnuelson theorem. The analysis is undertaken within the framework of a simple two-sector model. A major innovation of the study is to incorporate the role of trade barriers and subsidies in inducing skill-augmenting technological changes in import-affected sectors and, hence, in reducing the demand for and wages of unskilicd labor. In particular, factor bias arising from the move toward capital- and skill-based proctuction may have contributed to ocher trends in wage incquality. The paper finds that tradk prossures alone could not have been much of a reason for pronounced wage inequality.

Keyuomds: trade and wage inequality, trade barriers, subsidies, wage incquality

\footnotetext{
The paper was completed while the author was a visiting POSCO Fellow at the Fast-West Center in Honolulu, Hawaii. during the winter of 2004. Thanks are due to Dr. Nancy Lewris: Director of Research and to Dr. Charies Mforrison, President of the East-West Center for making avalable the rescarch facilitics. Thanks are also due to Wanling Huang for research assistance and to an anonymous referet of this journal for valuable suggestions.

Direct all correspondence in Jaleel Ahmad, Professor. Department of Fconomics, Concordia University, 1455 de Maissnneure Boulevard. West, Montreal, Quebec, H3G 1M8, Canada; Tel: 1-514-848-2424(39(0); F.mait: AHMJ@vax2.concordia.cil
} 


\section{INTRODUCTION}

large body of recent research has uncovered evidence of a decline in relative
wage of unskilled workers, and a widening wage dispersion linked to labor skills in the United States and the European Union (EU) since at least the early 1980s. ${ }^{1}$ These wage trends are accompanied by a decline in the share of the unskilled and a rise in the share of the skilled workers in total industrial employment. ${ }^{2}$ While these facts are generally undisputed, there is considerable disagreement as to their causes. As someone has remarked, the number of probable causes is as large as the number of suspects in the Murder on the Orient Express. Technological disloxations that reduce the demand for and wages of unskilled (or less skilled) workers have long been the prime suspects. But lately there has been a surge of writing on the possible conncction between tradc and wage inequality. ${ }^{3}$ In particular, the increasing trade with low-wage countries, in an implicit Stolper-Samuelson framework, is invoked as one of the major causes.

It has long been known that term-of-trade changes can shift relative wages in ways that produce greater inequality. What is seldom recognized is that protection and subsidies to industries vulnerable to import competition can significantly alter the outcome of shifts in terms-of-trade. They can do so in two prominent ways. First, protection and subsidies can neutralizc and offset a certain proportion of the trend of wage inequality that would have resulted from "natural" tcrms-of-trade changes. Setond, they can and to the trade-induced incopualities if they promote sector-specific technological changes that affect labor employment and wage structure. This is a plausible outcome if protection and over subsidies are directed toward capital-biased labor-saving technological change which reduces the demand for unskilled labor. ${ }^{4}$ Betrnan, Bound and Griliches (1994), and others, have highlighted the important tole that technological change has played in all industries, including those that are intensive in the use of unskilled labor, during the 1979-1989 period. Also, Sachs and Shatz (1994) find that during the 1979-1989 period the tate of growth of total factor productivity in sectors of lower skill-intensity was, in fact, higher than in sectors of higher skill-intensity. It is plausible that the observed technological change and productivity differentials are, at least partly, the result of trade policies themsetves that induced distressed industrics to structure in a way that increased the skill-intensity of production. In this way, the factor bias arising from trade policy does, indeed, add to other trends in wage inequality.

It is well-known that industrial country imports from low-wage countries are subject to substantially higher than average tariffs as well as quantitative restrictions (QRs), voluntary export restraints (VERs), and anti-dumping actions. These restrictions materialized as soon as low-wage imports started to put pressure on domestic import-competing industries. Also, industrial country protection of industries facing competition from low-wage imports has been supplemented since the late 1980 s with dircct government subsidies to increase investment and productivity in import-threatened labor-intensive 
industries. This may have pulled labor demand still further away from unskilled workers. Any analysis linking trade with low-wage countries to rising wage inequality in the OECD countries that is unable to concrol for the effect of trade barriers and subsidies misses important aspects of the problem.

The purpose of this paper is to introduce into the discussion the role of protection and subsidies in inducing skill-augmenting technological developments in import-affected sectors and, hence, in reducing the demand for and wages of unskilled labor. The role of trade policy secms important in this connection because it combines the effect of trade opening with the effect of sectoral growth in productivity as an explanation of both unemployment of the unskilled and the widening wage dispersion. In other words, narural terms-of-trarle changes may have been largely offset by protection. At the same time, the factor bias arising from subsidies may have added to other trends in wage inequality. Therefore, trade pressures alone could not have been much of a reason for wage inequality.

The rest of the paper is organized as follows. Section II discusses the interaction of the opening of trade with factor use and wages within the framework of a simple two-sector model. Wage and employment effects of trade barriers and subsidies are analyzed in Section III. Section IV discusses subsidy-led technological changes and their effects on employment and wage distribution. Sections V and Vl discuss allicd issucs and offer some conclusions.

\section{TRADE, FACTOR USE, AND WAGES}

The discussion in this paper revolves around a basic two-sector general equilibrium model that allows us to establish a unique relationship becween trade, goods and factor prices, production parterns, and wages. While the model is clearly a simplification, it, nevertheless, is a uscful framework to focus on some pertinent issues. The model underlines the way in which protection and direct subsidization of import-stressed industries can cause structural dislocations in factor use and affect employment and wage distribution.

A graphic version of the model is presented in Figure 1. The two production sectors which use two kinds of labor (shown on the axes) are (a) a sector ul producing a good intensive in the use of unskilled labor, which bears the brunt of import competition from low-wage producers abroad; and (b) another sector sL producing a good intensive in the use of a composite factor of skilled labor and capital, which for the sake of simplicity are lumped together. ${ }^{5}$ Production functions are characterized by constant returns to scale.

The tangency of the pre-trade factor price ratio $F_{1}$ (the ratio of the two wage rates) with isoquants of the two goods (not shown in the diagram) determines the relative average factor-intensity of the two sectors as $\mathrm{R}_{!}{ }^{\mathrm{x}}$ and $\mathrm{R}_{1}{ }^{y}$. The initial production equilibria and the allocation of unskilled and skilled labor (jointly with capital) can 
be determined by means of vector addition from the employment point $E$. These are shown as $\mathrm{q}_{1}{ }^{x}$ and $\mathrm{q}_{1}{ }^{y}$ for the $\mathrm{uL}$ and $\mathrm{sL}$ sectors, respectively.

Now, suppose that trade liberalization leads to a fall in the relative price of the ul-good in the domestic market. The change in terms of trade will lower the wage rate of unskilled labor with a "magnified" effect, in accordance with the Stolper-Samuelson theorem. The socially efficient outcome involves a transfer of labor from the uL-sector which shrinks to the sL-sector and increased employment and production in that sector. These long-run equilibria are shown at $\mathrm{q}_{2}{ }^{x}$ and $\mathrm{q}_{2}{ }^{\circ}$, with optimal factor relations given by rays $\mathbf{R}_{2}{ }^{x}$ and $\mathrm{R}_{2}{ }^{y}$ for $\mathrm{uL}$ and sL sectors, respectively. The changes in factor-intensity are in line with the falling real wage of unskilled labor.

\section{FIGURE 1.}

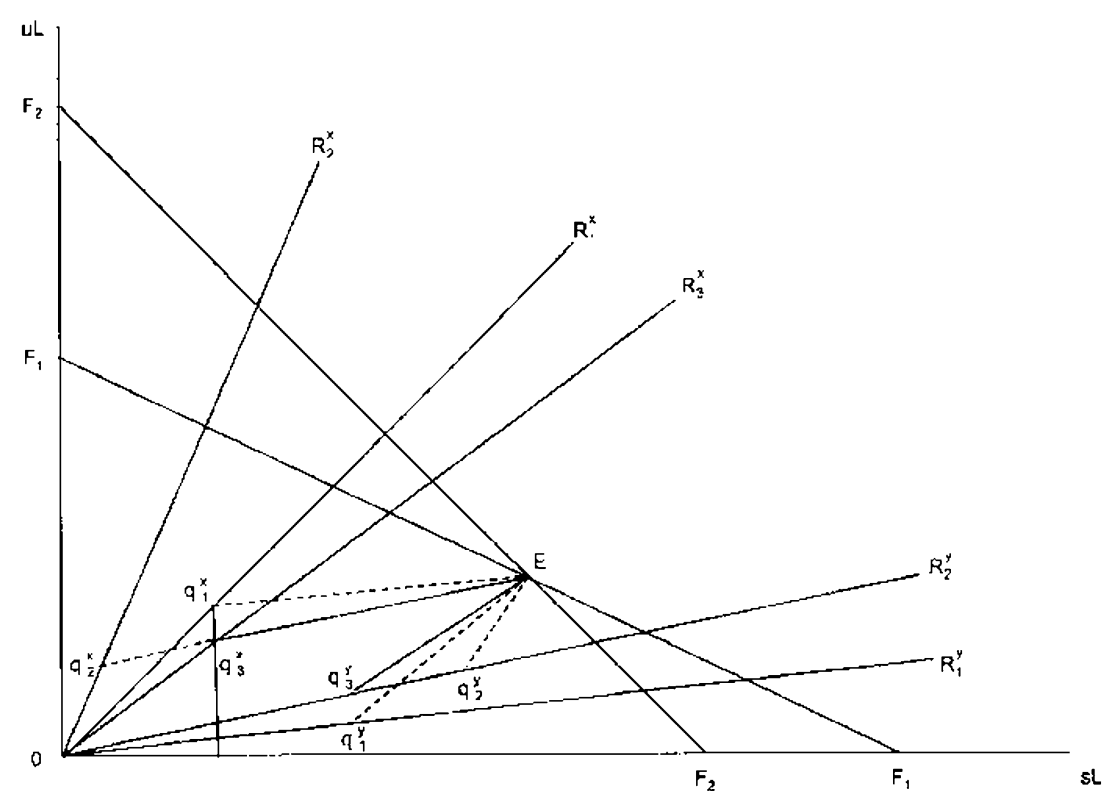

In the short run, unemployment of the unskilled labor (and possibly of the skilled as well) will result and may persist in a cyclical fashion throughout the adjustment to the long run ${ }^{6}$ These hindrances would be more pronounced if both kinds of labor were "specific" to their initial employment. These sort of short-tun effects on employment and earnings are probably what is caprured in studies by Haveman (1993) and Kletzer (1994) from the U.S. Displaced Workers Survey for the years 1981-1989.

The two-sector model presented in section II highlights the fact that the incipient change in the goods price ratio can be offset by means of tariffs and QRs on imports. If so, the one-to-one correspondence between goods and factor prices breaks down, 
and the connection between trade libctalization and wage incquality becomes tenuous. Consequently, the Stolper-Samuelson theorem is an apptopriate tool to explain wage inequality. If domestic prices do not fall, any observed increase in the volume of imports or in trade deficit is not sufficient to depress the wage of the unskilled. Increases in the volume of imports in a dynamic setting can also arise from the growth of domestic demand and the unwillingness of the domestic industry to increase production. The initial fall in prices, if not offset by trade barriers, can cause wage incquality, but a continuing risc in inequality requircs a continuing fall in prices. This is a basic problem with all current studics using the implicit Stolpor-Samuelson framework to link trade with inequality. A more satisfactory explanation of the fall in wages of the unskilled requires that trade barriers and direct subsidies to import-threatened sector's as well as the technological changes that they sponsor, must be brought into the picture.

It is well-known that trade barriers can prevent a fall in the domestic price of import-competing goods and may even incrcase it. The tendency of domestic prices to rise is almost certain in sectors subject to volume-based VERs, such as textiles, clothing, and footwear, where quality upgrading and higher export prices are a common obscrvation.

Available empirical evidence suggests that domestic prices of labor-intensive goods have, in fact, risen as a result of protection. Hufbauer, Berliner and Hlliott (1986, table 1.1, p.3-5) provide detailed data on changes in U.S. prices of import-competing goods induced by tariffs or tariff-equivalents of "special protection" for 31 L.S. industries. The "coefficient of price response", i.e., the ratio of induced increase in the domestic price to the tariff-equivalent rate of protection, is positive for all 31 sectors, and ranges between 0.3 and 0.8 . To take one example, the coefficient for textiles and clothing is 0.7 , and the induced increase in domestic price is estimated to range between 16 and 24 per cent during different phases of the MultiFiber Arrangement (MFA). ${ }^{8}$ More recently, Lawrence and Slaughter (1994) and Krugman and Lawrence (1994) have observed that prices of goods intensive in the use of unskilled labor either have not fallen or have moved in the oppositc direction.

In the light of contrary information on prices, it is misleading to arguc that any observed incqualitics in wages are caused by trade with low-wage countries. Correlations between rising imports and falling wage earnings do not denote causality. Wages of the unskilled could still fall in a bowdletized version of Stolper-Samuelson hypothesis of which the possibility has been raised by Freeman (1995). Workers threatened by import penetration may agree to take a wage cut in order to keep imports out.

Another method which has been used for estimating the effect of trade on labor markets is factor content analysis (Borjas et al. 1992; Sachs and Shatz 1994). Increased trade with low-wage countries is likely to have an adverse effect on wages of less-skilled workers to the extent that import-competing industries employ disproportionately large numbers of less-skilled workers. But, as Leamer (1996) has argued, if lower net exports of low-skill goods result from domestic sources (c.g., an increase in the 
relative supply of skilled labor) factor content analysis can be quitc misleading. In reviewing the role of the factor content, Katz and Autor (1999) observe that demand shifss and relative skill supplies appear to be much more significant factors in expanding the skill premium on wages than the impact of trade as measured by factor contents.

\section{TRADE BARRIERS, SUBSIDIES, AND TECHNOLOGY}

Unemployment and a fall in wages of the unskilled may also result indirectly from protection and subsidies. Trade barriers provide substantial incentives for productivity-enhancing investment by ensuring a protected market and higher prices. In practice, however, there are behavioral constraints that may blunt these incentives. Firms are unlikely to undertake costly investment in production facilities if the tariff-induced price increase is perceived as transitory and of an uncertain life. To the risk attendant on any investment must now be added the additional risk of withdrawal of protection without which higher domestic prices cannot be sustained. Trade barriers are seen by the industry as inherently uncertain, being subject to vicissitudes of political market and international pressure, even though ex post protection has had a long duration in a number of sectors. This is probably the reason why high and prolonged trade barriers have failed to generate anything more than a modest investment activity in protected industries.9 Nonetheless, trade barriers are freçuently used to coax the industry to reinvest its cash flow in upgrading production equipment. ${ }^{10}$

By contrast, when firms are given lump-sum investment subsidies the uncertainties that characterize trade barriers are eliminated altogether. A subsidy raises investment and output directly by financing or otherwise underwriting the investment, while trade barriers rely on raising investment indirectly by raising the profitability of production. Industrial countries of the OECD have responded to import penetration from low-wage countries with a bewildering array of subsidies and other government aids to assist beleagucred domestic industries. ${ }^{11}$ Trade-related subsidies mushroumed in all industrial countries since the late 1970s. ${ }^{12}$ Milnex (1988) points out that government aids over and above high trade brarriers to industry in individual EU countries arose initially to foster exports to each other before being directed exclusivcly to deal with rising levels of imports from poor countries. The subsidies were justified as being necessary to mitigate pressures for the demand of further protection.

A common form of trade-related subsidy has been the financing of capital expenditures in industries faced with a deteriorating international trade position, as manifested in rising import levels and a declining market share of domestic producers. 'Their purposes were variously described as "restructuring", "rejuvenation", and "conquering the domestic market". The strategies themselves were an eclectic nixture of investment in new and improved capital equipment, mechanization of labor-intensive segments, computer-assisted design and manufacturing, new production processes - all with a pronounced bias toward minimizing the use of unskilled labor. Available case study 
evidence indicates that utilization of high-skilled workers is positively correlated with capital intensity and the implementation of new technologies both across industries and across plants (Griliches 1969, Mark 1987, and others). Capital subsidies were, therefore, effectively a subsidy on employment of skilled labor. At the same time, product-mix was shifting toward higher end of the market.

Capital subsidies are motivated by the widespread perception that a large part of the distress in labor-intensive industries in industrial countries is caused by low-wage labor abroad, which needs to be offset by sufficiently large increases in labor productivity and technological innovations. The underlying presumption shared by industry and governments alike was that the loss of incemational competitiveness in many import-competing industries arose from past failures to invest in moxkm equipment and technology. Productivity-enhancing investment, it was argucd, would make the production of labor-intensive goods feasible cven in high-wage countrics.

\section{SUBSIDIES, FACTOR USSE, AND WAGES}

Public subsidies (combined with trade batriers) that promote skill-biased technological changes can lead to both labor-shedding and lower wages of the unskilled. Reverting to Figure 1, a subsidy for the use of skilled labor and capital in the uL sector results

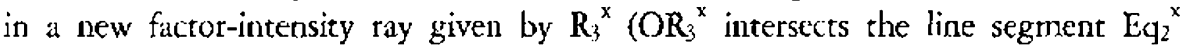
at the vortex of $\mathrm{q}^{x}{ }^{x}$ with the horizontal axis). The resulting allocation of factors corresponds to points $\mathrm{q}_{3}{ }^{x}$ and $\mathrm{q}_{3}{ }_{3}$. The ul. sector hecomes relatively more intensive in the use of skilled labor in comparison with its factor-intensity before opening of trade.

It is clear from Figure 1 that the post-subsidy equilibrium output of $u L$ sector still contracts, relative to the one before the change in terms of trade, while that of the sL sector expands, and the direction of adjustment is, at best, correct. But there are significant implications for employment, wages, and inequality. Capital subsidy has caused a fall in employment of unskilled labor in excess of trade barriers which could have stabilizard it at qu ${ }^{x}$. Measuring vertically, the fall in unskilled labor employment is equal to the line segment $\mathrm{q}_{1}{ }^{\mathrm{q}} \mathrm{q}_{3}{ }^{\mathrm{x}}$. It is easy to see that unemployment of the unskilled would be higher with a higher capiral subsidy, i.e., a clockwise rotation of the $\mathrm{R}_{3}{ }^{\mathrm{x}}$ ray. Moreover, if the factor substitution process is accompanied by a rise in total factor productivity (a downward shift of the isoquant with or without a skewness toward skilled labor) further unemployment would result.

Subsidized new investment has resulted in a marked increase in labor productivity in nearly all labor-intensive industries (particularly in textiles and clothing) - a conclusion shared by all industry analysts. 13 There is probably also an increase in total factor productivity as a result of technological innovations, although the empirical evidence on this is sparsc. ${ }^{14}$ But there is little doubt that while industries were shedding 
unskilled labor political support for continuing protection and further subsidies was garnered on grounds of preventing unemployment.

A large body of recent research has shown that much of the change in wage structure in the United States arises from the introduction of new technology (Machin and Reenen 1998, Johnson 1997, Berman, Bound and Griliches 1994, Bound and Johnson 1992). All available evidence points to a significant complementaricy of new technology with differences in wages of the skilled and unskilled workers in the Linited States as well as in other developed economies. Moreover, faster skill upgrading is concentrated in similat industries in different countries. In order to test the trade and wage inequality hypothesis, Machin and Reenen (1998) provide an empirical test of the proposition that industrics with faster- rising import intensities have reduced the proportion of their unskilled workers at a faster rate. In no case was the import variable correctly signed and significancly different from zcro (Table V, p. 1235). They conclude that "certain skill-based technological changes have favored the wage and employment prospects of relatively skilled workers while simultaneously damaging the wage and employment of the less skilled" (p. 1215).

The main alternative to trade-based explanation of wage inequality as well as of rising unemployment of the unskilled, thercfore, appears to be the one based on technology-driven changes in labor market. This paper has argued that technology-driven changes are reinforced, not so much from trade with low-wage countries per se, but by the ensuing trade barriers and subsidies which, in turn, induced labor-saving technological changes. One could argue that trade is still the uriginal "situ" but its relationship with wage ineçuality is indirect and much more subtle than postulated in Heckscher-Ohlin type of studies, such as Freeman (1995) and Wood (1994). A more plausible causation runs from increased trade leading to subsidies and trade barriers (indirect subsidies) which, in turn, lead to labor-saving technological changes. Changes in technology can, of course, arise exogenously, as they have in large parts of production sectors in OECD countries. But it is also plausible that trade with low wage countries has been the catalyst of technological changes in some labor-intensive sectors. This role has, at best, been modest.

\section{PATTERNS OF WAGE INEQUALITY}

A detailed discussion of measurement problems of wage inequality is outside the scope of this paper. But some comments on che more visible aspects of the problem will not be out of place. It was argued in this paper that the initial adverse impact of natural terms-of-trade changes on American wages was reinforced by protection and subsidies that followed trade libcralization. In particular, subsidies were responsible for factor bias of "modernization" strategies in import-competing industries. Much of the implicit and direct subsidization of import-thrcarened sectors was subsidization 
of capital and technology, ostensibly to neutralize the effect of cheaper labor abroad. But this might have pulled labor demand still further away from unskilled workers and toward the complementary bundle of skilled workers and equipment i.e. sector SL in Figure l. If so, this would have added to other trends in wage inequality. It is clear that unskilled workers were significant losens, both in terms of lower employment and in lower wages.

Nevertheless, the broader distributional implications of thesc trends are ambiguous and subject to conflicting interpretation. Since the unskilled labor sectors, particularly textiles, clothing and footwear, were subject to prolonged protection by trade barriers and subsidies, profitability in those scctors may have increased, and with it the average wage. All empirical evidence points to a significant rise in labor productivity in this sector. It is possible, of course, that productivity increases in the unskilled labor sector may not have led to significant increases in wages due to lower union density and generally weaker bargaining mechanism in the sector. Nonetheless, there is some evidence of an upward wage drift that tended to increase wage disparity within the sector, as segments of high productivity, e.g., computer-assisted design, garnered relatively higher wages. However, this was not sufficient to improve the relative position of this sector vis-à-vis the skilled labor sector.

A steep and sustained rise in wages in the skilled labor sector may have actually increased the wage dispersion between the two scetors, despite a productivity-led rise in average wage in the unskilled labor sector. Machin and Reenen (1998, table III) estimate that more $R$ \& D intensive industries have seen faster increase in wage-bill and employment shares in all seven OECD countries (including the Lnited States) in their sample. Given these multiple and contradictory dimensions, the widening wage dispersion does not appear to be related so much to trade liberalization as to a rapid diffusion of technology and the resulting escalation of wages in the skilled-labor sectors. The widening gap betwecn the wages of skilled and unskilled workers most likely also worscned the economy-wide distribution of income as it pulled the Lorenz curve down and away from the diagonal.

The analysis of wage inequality is complicated by the dichotomy between the short and the long runs. It is evident that modernization of parts of low-wage segments in import competing industries, chiefly textiles and apparel, has led to both greater unemployment and greater inequality in the short run But, from a long-run standpoint, this also had the benign effect of smoothing the transition toward a general improvement in productivity and living standards. It is doubtful whether the cause of income equality would have been better served by perpetuation of low-wage employment in sectors affected by trade liberalization. The maintenance of low-paying employment may initially prevent a worsening of income distribution, but the second round effects would definitely have been negative from the standpoint of improving living standards. In today's world, it is difficult to conceive of a contiauing rise in living standards without technological changes that may well increase income disparity in the short run. 


\section{CONCLUDING COMMENTS}

This paper has attempted a reexamination of the link between liberalization of trade with low-wage countries and growing wage inequality in industrial countries. Our analysis suggests that this link is, at best, tenuous since none of the papers is able to demonstrate convincingly that domestic prices of gouds that directly compete with low-wage imports have fallen. In fact, the evidence for the opposite tendency, i.e., of rising prices, is generally stronger. This is very simply due to the fact that imports from low-wage countries have been subject to high and prolonged trade barriers.

It was shown in this paper that the influence of subsidy-induced technological changes on wages appears to be much more critical. The sole purpose of investment subsidies was to raise productivity of labor in an attempt to compete with low-wage imports. The resulting changes in factor proportions and factor prices appear to be the cause both of unemployment of the unskilled and of a widening wage distribution. Trade with low-wage countries has undoubtedly caused dislocations in goods and factor matkets in certain import-competing industries but technology alone appears to be the decisive factor in wage inequality.

\section{REFERENCES}

Abraham, Katherine and Susan Houseman. 1993. Earning Inequality in Germany. NBER Working Paper No. 4541, Cambridge, Mass.

Berman, Eli, John Bound, and Zvi Griliches. 1992. Changes in the Demand for Skilled Labor Within U.S. Manufacturing Industries: Evidence from the Annual Survey of Manufacturing. NBER Working Paper, Cambridge, Mass., July.

Berman, Eli, John Bound and Stephen Machin. 1998. Implications of Skill-biased Technological Change: International Evidence, The Quarterly Journal of Econtmics: $1245-70$.

Bhagwati, Jagdish and Vivek Dehejia. 1994. Free Trade and the Wages of the Unskilled: Is Marx Striking Again. In Trade and Wages, ed. Bhagwati, J. and Marvin Kosters. Washington, D.C.: American Enterprise Institute.

Bhagwati, Jagdish. 1995. Trade and Wages: Choosing Among Alternative Explanations. Economir Policy Review. Federal Reserve Bank of New York, January: 42-47.

Bloom, David E. and Avi Bender. 1993. Labor and the Emerging World Economy. Population Bulletin 48 (2): 2-29.

Borjas, George, Richard Freeman and Lawrence Katz. 1992. On the Labor Market Effects of Immigration and Trade. In Immigration and the Work Force, ed. Borjas, George and Richard Freeman. Chicago: University of Chicago Press.

Borjas, George and Valeric Ramey. 1995. Foreign Competition, Market Power, and Wage Inequality. Quarterly Joumal of Economics CX: 1075-1110. 
Borjas, George and Valerie Ramey. 1994. Time Series Evidence on the Sources of Trends in Wage Incquality. American Economic Review, Papers and Proceedings 84: 10-16.

Bound, John and George Johnson. 1992. Changes in the Structure of Wages in the 1980s: An Evaluation of Alternative Explanations. American Economic Review: 371.42.

Canadian Industrial Renewal Board. 1984. Tbird Annual Report. Montreal.

European Communities Commission. 1989. Fint Survey on State Aids in the European Community. Luxembourg.

European Free Trade Association. 1986. Working Party on Government Aids, No EFTA/EC 11/86, Geneva.

Federal Reserve Bank of New York. 1995. Economic Policy Review 1 (1).

Fielke, Norman S. 1994. Is Global Competition Making the Poor Even Poorer. New England Ennomic Review (Novembor/Deccmber): 3-16.

Freeman, Richard. 199/4. How Labor Fares in Advanced Economies? In Working Under Different Rules, ed. Freeman R New York: Russell Sage Foundation.

Freeman, Richard B. 1995. Are Your Wages Set in Beijing? Joumal of Exonomic Perspectives 9 (3): $15-32$.

Freeman, Richard and Lawrence Katz. 1994. Rising Wage Inequality: The United States versus Other Advanced Countries. In Working Under Different Rudes, ed. Freeman, R New York: Russell Sage Foundation.

Gottschalk, Peter and Robert Moffitt. 1994. The Growth of Earnings Instability in the U.S. Labor Masket. Brookings Papers on Econumic Activity 2: 217-72.

Grum, D. 1980. Managing Industrial Change? French Policies to Promote Indastrial Adjustment. London: Department of Trade and Industry.

Griliches, Zvi. 1969. Capital-Skill Complementarity. Review of Economic and Statistics: 465-8.

Haveman, Jon. 1993. The Effect of Trade Induced Displacement on Lnemployment and Wages. Unpublished, October.

Hoffman, K. 1985. Clothing, Chips and Comparative Advantage: The Impact of Microclectronics on Trade and Protection in the Crarment Industry. World Detelopment 13: $371-92$.

Hufbauer, Gary Clyde. 1983. Subsidy Issue After the Tokyo Round. In Trade Policy in the 1980s, ed. Cline, William. Cambridge, Mass.: M.I.T. Press.

Hufbauer, Gary Clyde and Joanna Shelton Erb. 1984. Subsidies in International Trade. Washington, D.C.: Institute for International Economics.

Hufbauer, Gary Clyde, Diane T. Berliner, and Kimberly Ann Elliott. 1986. Trade Protection in the United States - 31 Case Studies. Washington, D.C.: Institute for International Economics.

Johnson, George. 1997. Changes in Earnings Inequality: The kole of Demand Shifts. Joumal of Economic Perspectives: 41-54.

Johnson, George E. and Frank P. Stafford. 1993. International Competition and Real Wager. American Econmmic Review, Papers and Procedings 83: 127-30. 
Karz, Iawrence F. and Kevin M. Murphy. 1992. Changes in Relative Wages, 1963-1987: Supply and Demand Factors. Quarterly Joumal of Econmics CVII: 35-78.

Kletzer, Lori G. 1994. International Trade and Job Loss in LS Manufacturing. 1979-1991. Unpublished.

Krugman, Paul and Robert Z. Lawrence, 1994. Trade, Jobs and Wages. Scientific American April: 44-9.

Krugman, Paul and Rohert Iawrence. 1993. Trade, Johs and Wages, NBER, Working Paper No. 4/78, Cambridge, Masis, September.

Iawrence, Robert and Marthew Slaughter. 1993. Trade and U.S. Wages: Great Sucking Sound in Small Hiccups? Brookings Papers on Economic Activity. Washington, D.C.: Brookings Institution Press.

Leamer, E. 1993. Wage Effects of a U.S. Mexican Free Trade Agreement. In The Mexico-l.S. Fre Trade Agrement, ed. P.M. Gatber. Cambridge, Mass.: M.I.T. Press. Leamer, E. I994. 'Irade, Wages and Revolving Door Ideas. NBER Working Paper No. 4716. Cambridge, Mass.

Leamer, E. 1996. In scarch of Stolper-Samuelson Effects on U.S. Wages. Working Paper No. 5427, NBER, Cambtidge, Mass.

I.evy, Frank and Richard J. Murnane. 1992. US Earnings Levels and Earnings Inequality: A Review of Recent Trends and Proposed Explanations. Joumal of Economic Literature 30: $1333-81$.

Machin, Stephen and John Van Reemen. 1998. Technology and Changes in Skill Structure: Evidence from seven OLCD Countries. The Quarterly Joumal of Economics: $1215-41$.

Mark, Jcrome. 1987. Tcchnological Change and Fmployment: Some Results from BLS Rescarch. Montbly Labor Review: 26-9.

Milner, Helen V. 1988. Resisting Protectionism: Global Industries and the Politic of International Trade. Princeton: Princeton University Press.

Mishel, Lawrence and Aaron Bernstein. 1994. The State of Working America, 1994-1995. New York: M.E. Sharpe.

Murphy, Keven M. and Finis Welch. 1992. The Structure of Wages. Quarterly Joumal of Economics CVIl: $285-326$.

OECD. 1983. Industrial Ldjustment and Government Suppont. Paris.

OECD. 1994. The OECD Jobs Siudy; Evidence and Explanations. Paris.

Oliviera-Martins J. 1993. Market Structure, International Trade and Relative Wages. Economics Department, Working Paper No. 134, OECD, Paris.

Price, Victoria. 1981. Industrial Policies in the European Conmunity. London: Trade Policy Research Center.

Richardson, J. David. 1995. Income Inequality and Trade: How to Think, What to Conclude. Journal of Economic Perspectives 9 (3): 33-56.

Renshaw, G. 1981. Employment, Trade and North-South Cooperation. ILO, Geneva. Revenga, Ana L. 1992. Exporting Jobs: The Impact of Import Competition on Employmont and Wages in U.S. Manufacturing. Quanterib Joumal of Fonomion February. Sachs, Jeff and Iloward Shatz. 199/. Trade and Jobs in U.S. Manufacturing. Brrokings 
Papers on Fconomics Activity 1: 1-84.

Topel, Robert. 1993. What Have We Learned from Empirical Studies of Employment and Turnover? American Economic Review, Papers and Proceedings 83: 110-15.

Tsao, James T.H. 1982. The Economic Effects of Export Restraints. USITC Publication No. 1256, International Trade Commission, Washington, D.C.

United Statcs, Department of Labor. 19)4. Repont on the American Wonk liome. Washington, 1). $\mathrm{C}$.

United States, Congressional Budget Office. 1986. Ilas Trade Protection Revitalized Domestic Industries? U.S. Congress, Washington, D.C.

Wolf, M. 1979. Adjustment Policies and Problems in Developed Countries, Staff Working Paper No. 349. Washington, D.C.: The World Bank.

Wood, Adrian. 1994. North-South Trade, Employment and Inequality. Oxford: Clarendon Press.

\section{ENDNOTES}

1 These are documented in Katz and Murphy (1992), Murphy and Welch (1992), Levy and Murname (1992), Berman, Bond and Griliches (1942), Bloom and Brender (1993), Juhn, Murphy and Pierce (1993), Toped (1993), Abrahaun and Houscman (1993), Mishel and Bernscein (1994), Gottschalk aurd Molfiti (1094), OECD (19\%4), Federal Reserve Bank of New York (1995).

The declinc in the relative position of unskilled and less skilled workers show up differenty in the Lnited States than in the EL. In the liniced States, the real hourly earnings of workers in the bottom decile have fallen rapidly. In the EU, on the other hand, the ratio of the employed to toral industrial labor force, as well as hours worked per simployee, has fallen. But, as pointed out in Frecinan (1964) and Kata and Freeman (1954), the rise in joblessness in the $\mathrm{EL}^{\circ}$ is che flip side of the rise in wage inecuuality in the United States. The two reflect the sanke general phenomenon of a relative derline in the demand for unskilled labor.

'See, for instance, Borjas, Freeman and Katz (1992), Murphy and Welch (145)2), Oliviera-Martisis (1993), Borjas and Rancy (1993, 1995), Wood (1994), Leamer (1993, 1994), and Sachs and Shatz (1994), Revenga (1992), Johnson and 5tafford (1995), and Richardson (1995).

1 As a prime example, the grant of protection to textile, clothing and footwcat indestries was, as a nle, contingene on the "modernization" of sectors most vulnerable to imports from low-wage countries.

skilled labor and capical in this noxdel are created as complements. But they are joindy substitutable with unskilled labor in both sectors.

6 The "dynamics" of adjustment to the long-run are not exploted in this paper.

For a fuller discussion, sec Bhagwati and Dehijia (1991) and Bhagwati (1959).

${ }^{*}$ This estimate is rematkably different. from the wotking assumption in Leamer (1995) which has falling textile and apparei prices.

9 Detailed case studies of protected industries in the U.S. has led the Congressional Budget Office (1986) to conclude that high tariffs, Vkiks, and trigger price mechanism did not lead to more than a modest increase in investment.

"Inder the I:S. Trade and Tariff Act of 1974, compulsory reinvestment programs were either directly financed or forced upon the industry as the "price" for granting "special" protection.

"Direct financial subsidies for the rescuc and survival of firms in import-competing industries in industrial countries ase extensively documented. More pertinent studies are Wolf (1979), Green (1980). Price (1981), Rerushaw (1981), Horn (1982), Tsao (1982), Hufbauer (1983), OECD (1983), J hutbauer and Frb (1984), Canadian Industrial Review Board (1984), Hoffman (1985), European Free Trade Association (1986), Milner (1988), and European Communicies Commission (1989).

12 The ratio of industrial subsidies to GDP in the Uinitcol States was consistently the lowest among industrial countrics (Hutbauer and Erb 1994 ?.

"These: developminits atc extensively reported in trade magazines and other specialized sources. In all 31 studies included in Hutbauer, Berliner and Elliot (1986) protection and subsidies were accompanied by ${ }_{14}$ productivity - enhancing technological changes in labor - intensive seccors.

${ }_{14}$ However, see Sachs and Stratz (199亿) for some limiced evidence. 